the court has been scrupulous to examine the preparatory work and seek therein confirmation of its views. ${ }^{17}$ It is still a significant fact that the cases have thus far manifested a striking absence of conflict between extrinsic evidence and what the plain or natural meaning of a text seemed to demand. On the other hand, the court appears to be increasingly aware of the danger of concluding that textual or linguistic clarity is necessarily indicative of clearness of design of the parties to an international instrument, and perhaps, under the salutory influence of Judge Anzilotti's dissenting opinion in the case concerning the Interpretation of the Convention of 1919 concerning Employment of Women during the Night, ${ }^{18}$ is reluctant to acknowledge that a text is verbally clear even when there is room for such a conclusion. ${ }^{19}$

In a word, the instant case reveals a departure in the method of approach which the court applies to the cases confronting it and justifies, in that regard, the testimony to that effect that is borne by the minority. An experience of twelve years has brought home to a great tribunal a sense of the importance of approaching a text concerning the construction of which there is divergence of opinion in such a way as to minimize the danger of misconceiving the actual design of the contracting parties, as well as a realization of the fact that that danger is not diminished and may even be enhanced if there is sought to be imputed to those parties, as by an applicable rule, an obligation to employ terms in a sense that was not in fact responsive to their actual design. The opinion concerning the Minority Schools in Albania, apart from the character of the conclusions reached, shows that the court is making progress in the performance of its interpretative tasks by breaking away from conventional statements calculated to impair both its freedom and success in getting at the truth.

Charles Cheney Hyde

\title{
ACTS AND JOINT RESOLUTIONS OF CONGRESS AS SUBSTITUTES FOR TREATIES
}

The failure of all efforts during the past twelve years to make the United States a member of the Permanent Court of International Justice, due to the opposition of a relatively small minority of the Senate (the vote on January 29, 1935 , in favor of adherence to the protocols was 52 ; that against adherence was

\footnotetext{
${ }^{17}$ See Advisory Opinion of Nov. 15, 1932, concerning the interpretation of the Convention of 1919 concerning the Employment of Women during the Night, Publications, Permanent Court of International Justice, Series A/B, No. 50, 365, 378. See, also, the Advisory Opinion No. 2 concerning the question whether agricultural labor was embraced within the competence of the International Labor Organization, $i d$., Series B, No. 2, p. 41; Case of the S.S.Lotus, id., Series A, No. 10, pp. 16-17; Advisory Opinion No. 14 concerning the jurisdiction of the European Commission of the Danube between Galatz and Braila, id., Series B, No. 14, pp. 28 and 31; Advisory Opinion interpretative of the Statute of the Memel Territory (Preliminary Objection), June 24, 1932, id., Series A/B, No. 47, p. 249.

${ }^{18}$ Publications, Permanent Court of International Justice, Series A/B, No. 50, 383.

19 See Judgment in the Lighthouses Case between France and Greece, March 17, 1934, Publications, Permanent Court of International Justice, Series A/B, No. 62, 13.
} 
36), ${ }^{1}$ has recently aroused discussion as to whether there is not a procedure by which this object can be accomplished other than through adherence to a diplomatic protocol, which is assumed to require the approval of two-thirds of the Senate to make it effective. If a method of procedure consistent with the Constitution can be found which would obviate the necessity of this extraordinary majority in the Senate, the obstacle which has until now prevented the United States from becoming a member of the court can easily be overcome. It is believed that such a mode of procedure can be found in the action of Congress, in the form of an Act or joint resolution, either of which can be passed by a simple majority of both Houses, authorizing the President to adhere to the protocols, or simply declaring that the United States accepts membership in the court, subject of course in the latter case to the willingness of the signatories to admit the United States to membership under that procedure. It is submitted that a protocol under which the United States proposes to become a member of an international organization, especially one which does not involve for the United States any commitments or legal obligations further than the annual appropriation of a small sum of money to cover its share of the common expense for the maintenance of the organization, does not necessarily require ratification by the President by and with the advice and consent of the Senate two-thirds of the Senators present concurring.

In practice, the United States has often become a party to protocols which had the full force of international engagements but which were not subject to ratification by the President by and with the advice and consent of the Senate. Some examples may be found in Malloy's Treaties, Conventions, etc. Between the United States and Other Powers, pp. 152, 723, 854, 871, 932, 936, $1144,1443,1460,1673,1688,1717,1870$ and 2006. Also Congress has frequently made appropriations of money for the support of international institutions when there was no treaty authorizing the appropriations. On May 2, 1932, Representative Linthicum introduced in the House a resolution appropriating $\$ 53,895$ as the share of the United States of the common expense for the maintenance of the Permanent Court of International Justice. The Committee on Foreign Affairs of the House made a favorable report on the resolution and no question appears to have been raised as to the constitutional authority of Congress to make the appropriation. ${ }^{2}$ If such an appropriation were made and continued permanently, the effect would be to make the United States for all practical purposes a member of the court, since that appears to be the only legal obligation which membership in the court involves, and as for the right of the United States to make use of the court, it already has that right.

Precedents in support of the view that the United States might, consistently with the Constitution, become a member of the court through the

${ }^{1}$ In the vote of January, 1926, the minority was still smaller, the vote being 76 for adherence and 17 against.

${ }^{2}$ As to this resolution see Hudson, in this Journal, Vol. 26 (1932), p. 794. 
action of Congress in the form of an Act or a joint resolution instead of through the conclusion of a treaty, do not seem to be lacking. In fact, the United States has on various occasions become a member of international organizations by this procedure, for example, the International Hydrographic Bureau (1921), and the International Statistical Institute (1924). The latest and most important instance of the kind was afforded by the joint resolution of June 19, 1934, which authorized the President "to accept membership for the government of the United States of America in the International Labor Organization." An invitation was promptly extended by the Organization to the United States and it was accepted on August 20, 1934, through a letter addressed by the American Consul in Geneva to the Director of the International Labor Office. ${ }^{3}$ It happens that the Senate voted unanimously for the resolution, but if it had been only by a bare majority that would have had no effect on the constitutional validity of the procedure by which the United States became a member.

It may be observed in passing that under the provisions of the constitution of the International Labor Organization (Part XIII of the Treaty of Versailles), by which the United States is now bound as a consequence of its acceptance of membership in the Organization, it will be obliged to submit to the compulsory jurisdiction of the Permanent Court of International Justice in certain cases and may be brought before the court at the instance of another member for failure to submit the draft conventions and recommendations of the International Labor Conference to the competent authority or authorities. Furthermore, the United States may be brought before the court on the charge of failure to comply with the terms of any international labor conventions to which it is a party. (See especially Articles 415, 417, 418 and 423.) It thus happens that while the Senate refused to give, by a two-thirds vote, its advice and consent to the resolution of adherence to the court protocols which would not have given the court any jurisdiction over the United States without its consent, it voted unanimously to make the United States a member of the International Labor Organization under which it will be subject to the compulsory jurisdiction of the court in certain cases.

It would seem beyond question that if it was competent for Congress by a joint resolution to make the United States a member of the International Labor Organization with the obligation which it carries of accepting the compulsory jurisdiction of the Permanent Court in certain cases, it is equally competent for Congress by the same procedure to make the United States a member of the court itself, when membership thereof would not involve the assumption of such an obligation. Acting on this view, Representative Lewis of Maryland introduced in the House of Representatives on January 24, 1935, a bill authorizing the President to adhere to the court protocols

3 Hudson, "The United States in the International Labor Organization," this JoURNax, Vol. 28 (1934), p. 671. 
including the "optional clause" of the statute of the court. The same object could be accomplished by a joint resolution authorizing the President to accept membership in the court without adhering to the protocols, provided of course that procedure were acceptable to the signatories to the protocols. It has even been proposed that the United States might join the League of Nations by this procedure. On this assumption, Senator Pope of Idaho on May 7, 1935, introduced a joint resolution in the Senate authorizing the President to "notify the appropriate authority of the League of Nations that the United States accepts membership in the League," subject to certain terms and understandings. Under this procedure, ratification of the Covenant by the President by and with the advice and consent of two-thirds of the Senate would be dispensed with.

If the United States were to become a member of the court through the action of Congress instead of through the diplomatic process, the President would be competent without treaty authorization to designate consular or diplomatic representatives of the United States to sit in the Council and Assembly of the League for the purpose of participating in the election of judges of the court. In practice, he has often, without treaty authorization, designated American citizens to sit as representatives of the United States in international conferences convoked by or held under the auspices of the League, and even in the Council of the League itself. A recent example was the designation by the President of the American Minister to Switzerland, to participate with the Council of the League in the selection of the Central Opium Board. Another instance was the designation of the American Consul-General at Geneva to sit with the Council of the League in 1931 and to participate in its discussions relative to Japan's action in Manchuria, in so far as they involved the question of the obligations of the parties to the Briand-Kellogg Pact.

Earlier precedents in support of the view that membership of the United States in the League of Nations or the Permanent Court of International Justice might be constitutionally effected through the medium of an Act or resolution of Congress are by no means lacking. As is well known, when the treaty of April 12, 1844, for the annexation of Texas failed to receive the approval of the Senate by a two-thirds vote as required by the Constitution (the vote was 16 for ratification and 35 against ratification), further effort to obtain ratification was abandoned and the annexation was accomplished by means of a joint resolution passed on March 1, 1845, by a simple majority, the vote in the Senate being 27 for the resolution and 25 against it. ${ }^{4}$ In this way the obstacle of a two-thirds vote in the Senate was avoided. That this was the object which the friends of annexation had in mind in resorting to the use of a joint resolution after the failure of the treaty, is clear from a communication of the Secretary of State, John C. Calhoun, to the United States Chargé d'Affaires in Texas, in which he said:

\footnotetext{
41 Moore, Digest of International Law, p. 454.
} 
It is now admitted that what was sought to be effected by the Treaty submitted to the Senate, may be secured by a joint resolution of the two houses of Congress incorporating all its provisions. This mode of effecting it will have the advantage of requiring only a majority of the two houses, instead of two-thirds of the Senate.

A somewhat similar case was the annexation of Hawaii to the United States by a joint resolution of July 7,1898 , after it became evident that a treaty signed on June 16, 1897, for annexation would not receive the approval of two-thirds of the Senate. A certified copy of the resolution was delivered on the 12th of August, 1898, to the President of the Republic of Hawaii by the Minister of the United States, when the formalities of the transfer took place. $^{5}$ It happens that the resolution was voted for by two-thirds of the Senate, but if it had been otherwise (as it was in the case of Texas) the procedure by which Hawaii was annexed to the United States could hardly have been challenged on the ground of unconstitutionality.

In 1911, President Taft desiring to effect a reciprocity tariff arrangement between the United States and Canada, but being aware that a treaty for this purpose would not be approved by two-thirds of the Senate, reached an understanding with the Government of Canada by which the legislatures of both countries were to pass Acts providing for certain tariff reductions on goods imported into their respective countries from the other. The Congress of the United States passed such an Act but the proposed arrangement failed because the Canadian Parliament refused to pass a similar Act. Had it done so it would have afforded an example of an international arrangement effected by joint legislative action rather than by treaty, and the constitutional validity of the arrangement would have been beyond question.

As is well known, the President of the United States has often entered into trade or tariff reciprocity agreements with other countries in pursuance of authority conferred by acts of Congress, passed by a simple majority of both houses. Both Presidents McKinley and Theodore Roosevelt concluded a number of such agreements under authority of Section 3 of the Tariff Act of 1897. Their constitutional validity was upheld by the Supreme Court. B. Altman and Company v. The United States, 224 U. S. 583 . Somewhat similar authority was conferred on the President by the Trade Agreements Act of June 12, 1934, and a number of trade agreements have been concluded with foreign countries in pursuance of the Act, while others are now in process of negotiation.

As is equally well known, Congress has conferred authority on the Postmaster-General to conclude postal conventions by and with the advice and consent of the President but without the necessity of ratification with the consent of two-thirds of the Senate. The constitutional competence of Congress to confer such authority on the Postmaster-General was upheld by

51 Moore, op. cit., p. 510. 
Solicitor General Taft in 1890. 19 Ops. Atty. Gen., p. 520. Probably no one today could be found who would challenge that competence.

Under authority of the Act of Congress of February 9, 1922, the World War Foreign Debt Commission concluded agreements with various foreign countries for the funding of their war debts to the United States. These agreements were approved by the President and Congress but were not subject to ratification by the President by and with the advice and consent of the Senate two-thirds of the Senators concurring. In some cases (e.g., the agreement with Italy) the vote of the Senate was less than two-thirds, which would have been required had the agreements been in the form of treaties concluded by the treaty-making organs. But the constitutional validity of the agreements has not for this reason been contested.

Finally, it may be observed that the procedure of joint resolution was employed by the United States for declaring the termination of the war with Austria and Germany. Although in the past, international wars have almost invariably been terminated by the conclusion of a treaty of peace between the belligerent parties, in these cases it was done by Congressional action in the form of joint resolutions passed on July 2, 1921, declaring "that the state of war declared to exist" between the United States and Germany and between the United States and Austria on April 6 and December 7, 1917, respectively, "is hereby declared at an end." There was some opposition in Congress to the resolution by certain members who denied the constitutional competence of Congress to make peace by means of a resolution, but it was the view of the majority that since the state of war had been created by resolution of Congress, it could be terminated by the same authority and by the same procedure. ${ }^{6}$

The conclusion of the whole matter would seem to be that if it is within the constitutional competence of Congress by means of Acts or joint resolutions passed by a simple majority vote of both Houses and approved by the President, to make the United States a member of such institutions as the International Labor Organization, to annex foreign territory to the United States, terminate war with foreign countries, to authorize commissions to conclude foreign debt funding agreements, to authorize the PostmasterGeneral to conclude postal conventions and to empower the President to enter into trade and tariff agreements with foreign countries, it could certainly by either of these processes make the United States a member of the Permanent Court of International Justice and possibly also a member of the League of Nations. Indeed, it is believed, that Congress might with the approval of the President, create a relationship or undertake an engagement on behalf of the United States with a foreign state or states, in respect to any matter which is a proper subject of international regulation, or it might authorize the President to do so, provided it were within the constitutional

- See Anderson, "The United States Congressional Peace Resolution," this Journar, Vol. $14(1920)$, p. 384 . 
competence of the Congress to deal with such matter at all. The delegation by the Constitution to the President and the Senate of the power to make "treaties" does not exhaust the power of the United States over international relations. The will of the nation in this domain may be expressed through other acts than "treaties" and such acts do not necessarily need to be ratified by the President by and with the advice and consent of the Senate in order to be valid and binding, unless they so expressly provide by their own terms. In short, the power of the President and the Senate to regulate foreign relations is not an exclusive power; it is only when an agreement takes the form of a "treaty," as that term is used in the Constitution, that this power belongs exclusively to them. There is no inconsistency between the authority of the President and the Senate to regulate foreign relations through agreements in the form of "treaties" and the power of the President and Congress to deal with matters of foreign policy through legislative action. Which of the two procedures shall be employed in a given case is a matter of practical convenience or political expediency rather than of constitutional or international law. If the procedure of treaty regulation proves ineffective in a particular case because of the constitutional impediment relative to ratification, there is no reason of constitutional or international law why recourse to the easier alternative of legislative action cannot be had, if the President and a majority of the two Houses of Congress so desire, as has been done with success on various occasions in the past.

JAMES W. GARNer

\section{DECLARATORY JUDGMENTS IN INTERNATIONAL LAW}

In its decisions No. 7 and No. $13^{1}$ and on other occasions ${ }^{2}$ the Permanent Court of International Justice has asserted its power to render "purely declaratory judgments," that is, judgments between litigants which conclusively determine their rights but to which no coercive decree is appended. The Permanent Court affirmed in Judgment No. 7 that Article 63 of the Statute of the Court, ${ }^{3}$ as well as Article 36 providing for obligatory jurisdiction for the determination of a question of law or fact, ${ }^{4}$ contemplated judgments having a "purely declaratory effect." In Judgment No. 13 the court stated that Judgment No. 7, on the legal position of the German-owned factory at Chorzow, was "in the nature of a declaratory judgment, the intention of which is to ensure recognition of a situation at law, once and for all and with binding force as between the parties; so that the legal position

${ }^{1}$ Series A. No. 7, p. 19; A. No. 13, p. $20 . \quad{ }^{2}$ Series B. No. 11, p. 30.

$s$ "Whenever the construction of a convention to which States other than those concerned in the case are parties is in question, the Registrar shall notify [them]; . . . the construction given by the judgment will be equally binding upon it."

"I.e., jurisdiction over "the interpretation of a treaty" or "any question of international law" or "the existence of any fact which, if established, would constitute a breach of an international obligation." 